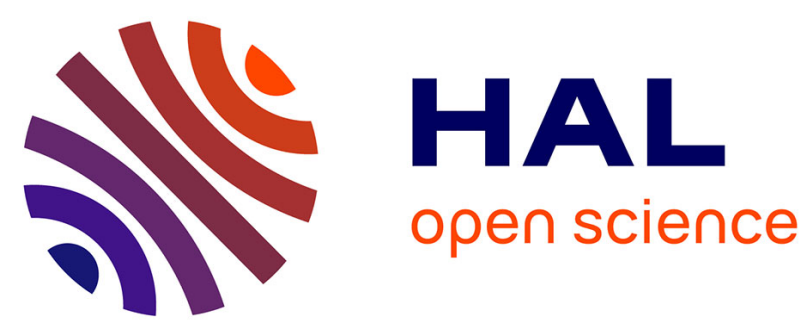

\title{
Diversity of decay resistance strategies of durable tropical woods species: Bocoa prouacencsis Aublet, Vouacapoua americana Aublet, Inga alba (Sw.) Wild
}

Nadine Amusant, M Nigg, Bernard Thibaut, Jacques Beauchêne

\section{- To cite this version:}

Nadine Amusant, M Nigg, Bernard Thibaut, Jacques Beauchêne. Diversity of decay resistance strategies of durable tropical woods species: Bocoa prouacencsis Aublet, Vouacapoua americana Aublet, Inga alba (Sw.) Wild. International Biodeterioration and Biodegradation, 2014, 94, pp.103-108. 10.1016/j.ibiod.2014.06.012 . hal-01321162

\section{HAL Id: hal-01321162 \\ https://hal.science/hal-01321162}

Submitted on 25 May 2016

HAL is a multi-disciplinary open access archive for the deposit and dissemination of scientific research documents, whether they are published or not. The documents may come from teaching and research institutions in France or abroad, or from public or private research centers.
L'archive ouverte pluridisciplinaire HAL, est destinée au dépôt et à la diffusion de documents scientifiques de niveau recherche, publiés ou non, émanant des établissements d'enseignement et de recherche français ou étrangers, des laboratoires publics ou privés. 


\title{
Diversity of decay resistance strategies of durable tropical woods species: Bocoa prouacencsis Aublet, Vouacapoua americana Aublet, Inga alba (Sw.) Wild
}

\author{
N. Amusant ${ }^{\text {a, }}$, M. Nigg ${ }^{b}$, B Thibaut $^{c}$, J. Beauchene ${ }^{\text {a }}$ \\ ${ }^{a}$ CIRAD UMR Ecologie des forêts de Guyane, BP 709, 97387 Kourou, France \\ ${ }^{\mathrm{b}}$ Université Pavillon Abitibi-Price, 2405, rue de la Terrasse, Local 2130 Université Laval, Québec, Québec, Canada

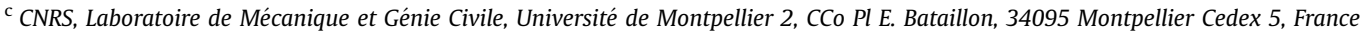

Keywords:

Decay resistance

Heartwood

Sapwood

Wood extractive

Density

Tropical wood

\begin{abstract}
The study of decay resistance in wood is of interest for wood end-users but also for the global carbon balance since wood biodegradation is a key driver of forest ecosystem functioning through its impacts on carbon and nutrient cycling. We studied the density and wood extractive contents in order to understand decay resistance against soil microflora after 90 days exposure of sapwood and heartwood from three Neotropical wood species known for their decay resistance: Bocoa prouacensis, Vouacapoua americana, Inga alba. Decay resistance was correlated with density more than wood extractive content. The results highlighted different decay resistance strategies. In B. prouacensis, both sapwood and heartwood were highly resistant due to the high density and high content of antifungal wood extractives. In $V$. americana heartwood, decay resistance was due to the high synergistic-acting wood extractive content. Conversely, with the least dense wood species I. alba, we found that decay resistance was due to the antifungal wood extractives synthesized early in the sapwood. In conclusion, we showed that the three wood species with the same level of heartwood decay resistance performance had different decay resistance strategies according to the anatomic and defensive wood traits.
\end{abstract}

\section{Introduction}

The study of wood's decay resistance is of crucial interest for wood end-users but also for the global carbon balance as wood biodegradation is a key driver of forest ecosystem functioning through its impacts on carbon and nutrient cycling. The factor controlling wood biodegradation and their interaction with the environment are still poorly understood and consequently wood biodegradation is incorporate in global carbon model in highly generalized forms (Cramer et al., 2001; Cornwell et al., 2009). There have been substantial numbers of studies on wood biodegradation particularly from temperate and boreal ecosystem but there is a striking knowledge gap for wood biodegradation rate and processes in tropical forest. The missing of knowledge could be at the origin of approximations and more studies on biotics determinants of wood biodegradation rates linked to trait contribution to wood biodegradation are needed to reduce uncertainties in global carbon cycling models. Chemical and anatomical wood traits play a key role on decay resistance and are useful in predicting biodegradation of woody species (Cornwell et al., 2009).

Van Geffen et al. (2010) studied the wood decomposition trait relationship using a large set of traits of potential importance on wood biodegradation. He concluded that tree diameter at breast height $(\mathrm{DBH})$ played a key role because the surface aera: volume ratio affect the accessibility to the substrate to by micro-organisms. But he signaled also that wood density was an unimportant trait for predicting interspecific differences in wood decomposition. This is, however, in line with the results of a global meta-analysis of 36 wood decomposition studies, which showed that wood density could not explain the difference in decomposition rates between gymnosperms (lower wood density, slower decomposition) and angiosperms decomposing in a common environment (Weedon et al., 2009). While other authors showed that: the denser woods are less degraded (Yamamoto and Hong, 1994; Chave et al., 2009). The chemical trait played also a key role as lignin (Syafii et al., 1988). About, secondary metabolites, there is large variation in the amount of secondary chemicals in wood, especially among tropical angiosperms (Cornwell et al., 2009). Heartwood formation is 
chemical defense mechanism that takes place between the sapwood and heartwood. During heartwood formation, secondary metabolites such as tannins, gums, and other colored materials accumulate in the heartwood. Consequently, wood decay resistance is acquired as a result of heartwood formation (Taylor and Gartner, 2002). All types of insects and pathogenic fungi are confronted with a less permeable tissue (Neya et al., 2004) impregnated with insecticidal (Rodrigues et al., 2011) and/or antifungal compounds (DeBell et al., 1999; Niamké et al., 2012). Rodrigues et al. (2009) documented a diverse range of defense mechanisms in tropical wood species: Eperua falcata impregnates its wood with large amounts of weakly antifungal compounds acting in synergy, while Tabebuia serratifolia and Sextonia rubra woods are naturally impregnated with antifungal agents. Van Geffen et al. (2010) concluded that the inhibiting effect of phenolic extractives on wood decomposition rates is not correlated; the amount of phenolic extractives cannot explain inter-specific variation in wood decomposition. But, the chemical nature of the wood extractives is preponderant and is one of the reasons why some low-density timbers such as Cedrela spp. are more resistant (e.g. fungal decay) than high density wood species (Antwi-Boasiako and Pitman, 2009). The causes of decay resistance are complex and take into account the wood extractives or density alone is not so simple.

The comprehension of the causes of decay resistance of wood allows to understand the influence of some traits like anatomical, chemical ones in biodegradation processes. This study was carried out to gain insight into the cause of decay resistance of three durable wood species: Bocoa prouacensis Aublet, Vouacapoua americana Aublet, Inga alba (Sw) Wild, by studying density, wood extractive content in sapwood and in the heartwood and secondly by establishing correlations with decay resistance against soil microflora. We focused on new data which could highlight the diverse range of decay resistance strategies in these three durable wood species.

\section{Materials and methods}

\subsection{Plant material and sampling}

We collected stems (Paracou Forest $5^{\circ} 15^{\prime} \mathrm{N}, 52^{\circ} 55^{\prime} \mathrm{W}$, in French Guiana), of three wood species belonging to Fabaceae and known for their resistance against wood-rotting fungi: Bocoa prouacensis Aublet (classified as very durable wood, class 1), Vouacapoua americana Aublet (classified as a very durable wood, class 1), Inga Alba (Sw.) Wild (classified as a durable wood, class 2). We also collected a non-durable species Virola michelii Heckel (Myristicaceae) with undifferentiated heartwood in order to control the virulence of the soil microflora during the bioassays. Two trees per wood species were harvested. A central board $(50 \times 620 \mathrm{~mm}, \mathrm{~T}, \mathrm{~L})$ including the pith was sawn from each log (Fig. 1). From each central board, two opposite boards including sapwood and heartwood were obtained $(50 \times 620 \mathrm{~mm} \mathrm{T,} \mathrm{L})$. Test specimens from opposite radius were considered as twins. Each board was radially subdivided $(25 \times 620 \mathrm{~mm}, \mathrm{~T}, \mathrm{~L})$ in order to obtain twin boards (Fig. 1): "A" boards for "decay tests" "B boards for "wood chemistry tests and density measurements. For the three measurement properties, test specimens were prepared only from both the outer sapwood and heartwood. The "A" and "B" boards were conditioned at $65 \%$ relative humidity ( $\mathrm{RH}$ ) and $20 \pm 2{ }^{\circ} \mathrm{C}$, until stabilization of the mass.

\subsection{Wood decay tests}

\subsubsection{Sampling material}

Each "A" board from the outer sapwood and outer heartwood was radially cut into one stick $(2 \times 10 \times 620 \mathrm{~mm} \mathrm{T,} \mathrm{R,} \mathrm{L),} \mathrm{i.e.} \mathrm{two}$ sticks for both radil positions. Each stick was sliced lengthwise into six test specimens $(2 \times 10 \times 100 \mathrm{~mm}, \mathrm{~T}, \mathrm{R}, \mathrm{L})$ : for each radial position, the test specimens of the three first sticks were considered as control and the three others were assessed for decay resistance tests. All the test specimens were conditioned at $65 \pm 5 \% \mathrm{RH}$ and $20 \pm 2{ }^{\circ} \mathrm{C}$ until exposure to soil microflora. Before exposure, the controls and test specimens were weighed (M1). Controls were dried at $103{ }^{\circ} \mathrm{C}$ for $24 \mathrm{~h}$ and then weighed (M01). The moisture content calculation (MC, Eq. (1)) allowed us to determine the reference dry matter M02 (Eq. (2)) of the test specimens (Amusant et al., 2008). For each wood species, we used 12 test specimens and 12 controls per radial position (sapwood and heartwood) respectively for decay test and moisture content determination.

$\mathrm{MC}=(\mathrm{M} 1-\mathrm{M} 01) \times 100 / \mathrm{M} 01$

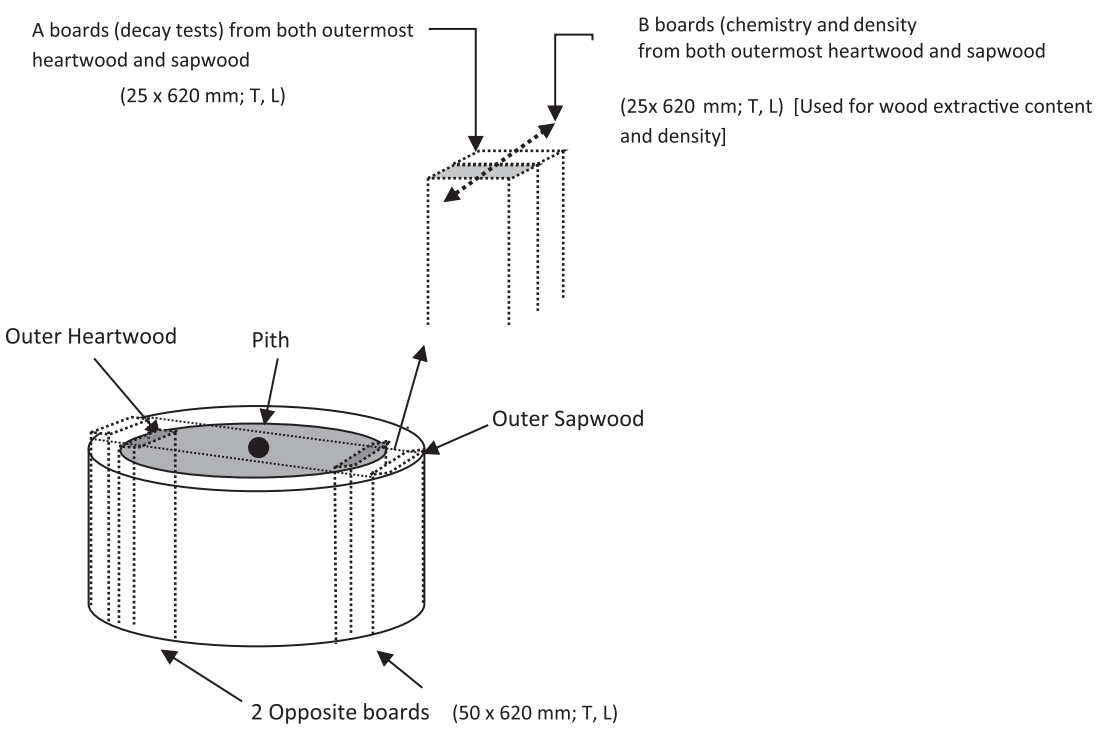

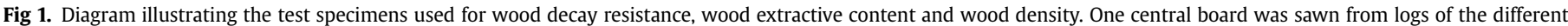

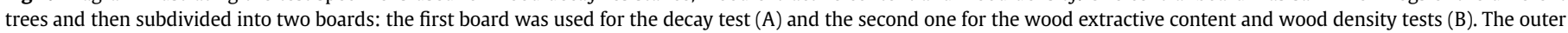
heartwood is shown in grey and the outer sapwood in white. Total boards/tree: 4 A boards and 4 B boards from the sapwood and the heartwood for each wood species. 
$\mathrm{M} 02=(100 \times \mathrm{M} 1) /(\mathrm{H}+100)$

$\mathrm{MC}=$ moisture content

M1 = mass of test specimen and control after conditioning (65\% HR; $21^{\circ} \mathrm{C}$ ).

M01 = dry mass of control.

M02 $=$ reference dry mass of test specimen.

\subsubsection{Decay resistance: soil bed test}

Wood test specimens were placed in contact with soil according to the procedure described by the American Wood Protection Association using the standard AWPA E14-07 (2007) method in soil beds. The test specimens were placed vertically in the soil leaving half of length exposed. In these conditions, a moisture gradient in the wood allows attack by large population of micro-organisms: basidiomycetes and soft rot ... (Nicholas and Crawford, 2003). The test specimens were exposed to the soil microflora for 90 days. Each test specimen was collected, carefully cleaned, weighted (M2), and then dried $\left(103^{\circ} \mathrm{C}\right.$ for $24 \mathrm{~h}$; M3). The final moisture content (Eq. (3)) and experimental mass losses (ML, Eq. (4)) were determined for individual test specimen as well as the mean values \pm SD (standard deviation) of 12 replicates measurements per radial position (sapwood and heartwood) and each wood species.

Final moisture content $=[(\mathrm{M} 2-\mathrm{M} 3) \times 100] / \mathrm{M} 3$

$\mathrm{ML}=[(\mathrm{M} 02-\mathrm{M} 3) \times 100] / \mathrm{M} 02$

M2 = mass of test specimen after exposure.

M3 = dry mass of test specimen.

M02 = reference dry mass of test specimen.

$\mathrm{ML}=$ experimental mass losses.

\subsection{Density}

The density at $12 \%\left[D_{12}\right]$ was determined after conditioning $(65 \%$ relative humidity, $20^{\circ} \mathrm{C}$ ), according to the NF B 51-002 standard (AFNOR, 1942). From B boards, two sections were cut $(20 \times 20 \times 620 \mathrm{~mm} \mathrm{R}, \mathrm{T}, \mathrm{L})$ respectively in both outer sapwood and heartwood. From each section three cubes were cut $(20 \times 20 \times 20 \mathrm{~mm} \mathrm{R}, \mathrm{T}, \mathrm{L})$ to measure the density. The test specimens were weighed $(\mathrm{g})$ and measured according the three directions $\mathrm{L}, \mathrm{T}, \mathrm{R}$ $(\mathrm{mm})$ in order to determine the volume $\left(\mathrm{cm}^{3}\right) . D_{12}\left(\mathrm{~g} / \mathrm{cm}^{-3}\right)$ was calculated according to the equation $D_{12}=\mathrm{m} /(1 \times \mathrm{r} \times \mathrm{t}$ ) (with 1 length, $r$ radial, $t$ tangential, $\mathrm{cm}$ ) and $\mathrm{m}(\mathrm{g})$ at the conditioned mass at $65 \% \mathrm{HR}, 20^{\circ} \mathrm{C}$. For each wood species, we used a total of 12 test specimens per radial position (sapwood and heartwood). Density was determined for individual test specimen as well as the mean value \pm SD (standard deviation) of 12 replicates measurements.

\subsection{Extractive content}

The other part of the previously conditioned "B" boards $(65 \%$ $\mathrm{RH} ; 20^{\circ} \mathrm{C}$ ) from both outer sapwood and heartwood was ground to $0.5 \mathrm{~mm}$ particle size in a Retsch SM 100 . Wood powder $(1 \mathrm{~g})$ was extracted successively with ethanol 96\% (analytical grade) and distilled water $(250 \mathrm{~mL}$ ) according to the Soxtec method (SousaCorreia et al., 2007). The solvents were evaporated under reduced pressure. The crude extracts were weighed to determine the percentage of ethanolic, aqueous and total extractive content. For each wood species, we used a total of 12 test specimens per radial position (sapwood and heartwood). The percentage of ethanolic, aqueous and total extractive content were determined for individual test specimen as well as the mean value \pm SD (standard deviation) of 12 replicates measurements per radial position (sapwood and heartwood) and for each wood species. Ethanol allows extraction of moderately polar phenolic compounds and residual lipophilic compounds. The addition of water improves the extraction of glycosylated phenolic compounds and phenolic with a high polymerization rate. Water also enables the extraction of soluble carbohydrates and proteins which can polymerize with polyphenolics to form a colloidal complex.

\subsection{Statistical analysis}

The XLSTAT software package (2013, Paris, France) was used for the logarithmic, nonparametric Spearman correlations between the density, mass losses and final humidity because of the absence of normality. A non-parametric Kruskall-Wallis test followed by multiple pairwise comparisons using Dunn's procedure/two-tailed test allowed us to compare the wood species decay resistance and wood extractives content. A principal component analysis (PCA) was used to visualize the effect of density and wood extractives content on decay resistance. Values were considered to be statistically significant at $p<0.05$.

\section{Results}

Table 2 shows Pearson correlations between decay resistance and wood properties (density and wood extractive content) and also the final moisture content observed after soil microflora exposure, a factor which influences the biodegradation level. Decay resistance was highly correlated with final humidity $\left(R^{2}=0.84\right)$ and negatively correlated with density $\left(R^{2}=-0.65\right)$. The decay resistance rate was the same as the rate for heartwood from the four wood species: B. prouacensis $(1.05)>V$. americana $(0.99)>I$. alba (0.67). V. michelii (control): the lowest density species had the highest proportion of vacuum containing a high level of water (Fig. 2). We observed that the porosity which favors the kinetics of fungal attack and access to the wood tissue was higher in wood with higher moisture uptake in species with small density. In conclusion, high density limits the wood biodegradation kinetics due to the pore size and the time required for the wood to reach the fiber saturation point, which is propitious for mycelia attack.

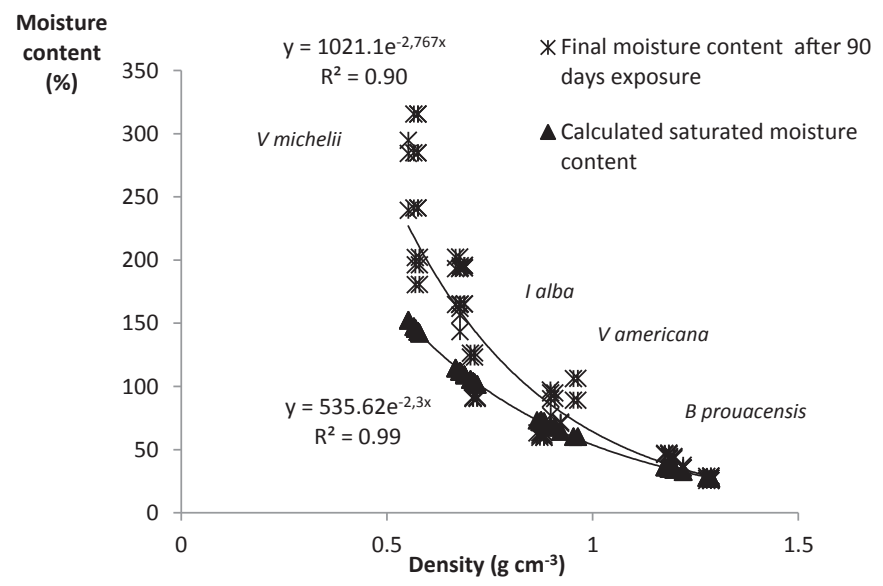

Fig. 2. Relationships between density and final moisture content after 90 days exposure of four wood species: V. michelli (control), B. prouacensis, V. americana, I. alba (*); Relationships between density and Calculated saturated moisture content with $\mathrm{D}_{12}$ at the beginning of the bioassay $(\boldsymbol{\Delta})$. Calculated saturated moisture content $=1 /($ wood specific gravity) - (1/1.5). Wood specific gravity $=0.872 \times D_{12}$ according to Chave et al., 2006 with $D_{12}=$ density at $12 \% ; 1.5=$ wood material specific gravity (Kolleman and Cote, 1984). 
Table 1

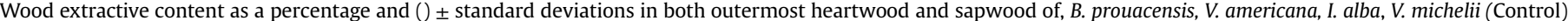

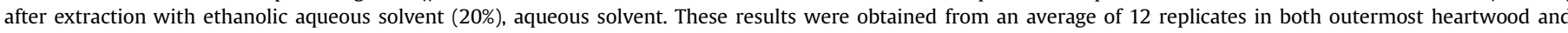
sapwood.

\begin{tabular}{|c|c|c|c|c|c|c|}
\hline \multirow[t]{3}{*}{ Species $^{\mathrm{a}}$} & \multicolumn{2}{|c|}{${ }^{\mathrm{a} E t h a n o l i c ~ c o n t e n t ~(\%) ~}$} & \multicolumn{2}{|c|}{ Water content (\%) } & \multicolumn{2}{|c|}{ Total content (\%) } \\
\hline & \multicolumn{6}{|l|}{ Tissue } \\
\hline & Sapwood & Heartwood & Sapwood & Heartwood & Sapwood & Heartwood \\
\hline Virola michelii & $2.8(0.0)^{\mathrm{ab}[\mathrm{a}]}$ & $2.4(0.06)^{\mathrm{a}}$ & $2.3(0.50)^{\mathrm{ab}}$ & $2.2(0.25)^{\mathrm{ab}}$ & $5.1(0.25)^{\mathrm{ab}}$ & $4.6(0.25)^{\mathrm{a}}$ \\
\hline Bocoa prouacencis & $2.1(0.72)^{a}$ & $6.0(1.37)^{\mathrm{abc}}$ & $2.1(0.21)^{\mathrm{ab}}$ & $1.36(0.22)^{\mathrm{a}}$ & $4.2(0.22)^{\mathrm{a}}$ & $7.3(0.22)^{\mathrm{abc}}$ \\
\hline Vouacapoua americana & $11.2(2.21)^{\mathrm{bc}}$ & $22.9(2.63)^{c}$ & $6.3(0.51)^{\mathrm{b}}$ & $1.11(0.28)^{\mathrm{a}}$ & $17.5(0.51)^{\mathrm{bc}}$ & $24.0(0.28)^{\mathrm{c}}$ \\
\hline Inga alba & $10.49(3.11)^{\mathrm{bc}}$ & $6.23(0.74)^{\mathrm{abc}}$ & $2.57(0.3)^{\mathrm{ab}}$ & $1.36(0.23)^{\mathrm{ab}}$ & $13.06(0.51)^{\mathrm{bc}}$ & $7.59(0.23)^{\mathrm{abc}}$ \\
\hline
\end{tabular}

${ }^{a}$ Wood extractive contents with different letters are significantly different at $p<0.5$, as determined A non-parametric Kruskall-Wallis test followed by multiple pairwise comparisons using Dunn's procedure/two-tailed test.

Table 2

Pearson correlation coefficients for final moisture content (Eq. (3)) after soil microflora exposure, mass losses and density.

\begin{tabular}{llll}
\hline Variables & Mass losses (\%) & $\begin{array}{l}\text { Moisture } \\
\text { content }\end{array}$ & $\begin{array}{l}\text { Density } \\
\left(\mathrm{g} \mathrm{cm}^{-3}\right)\end{array}$ \\
\hline Mass losses (\%) & 1 & & \\
Moisture content & $-0.84^{(* * *)}$ & 1 & 1 \\
Density $\left(\mathrm{g} \mathrm{cm}^{-3}\right)$ & $-0.65^{(* * *)}$ & $-0.86^{(* * *)}$ & 1 \\
\hline
\end{tabular}

*** Statistically significant at the $99.999 \%$ confidence level; **; statistically significant at the $99.99 \%$ confidence level.

Conversely, the wood extractive content contributed less to the decay resistance $\left(R^{2}=-0.31\right)$. The heartwood decay resistance rating was: $B$. prouacensis $>V$. americana $\approx I$. alba and differed from the wood extractive content rating: $V$. americana > I. alba $\approx$ B. prouacensis (Table 1 ).

The PCA analysis confirmed the significant correlation of decay resistance and density (Fig. 4). The first PCA axis thus represents the density and decay resistance on one hand and the second axis represents the effect of wood extractive content. We observed that $B$. prouacensis showed the most resistant heartwood but also the lowest total extractive content in both sapwood and heartwood. In contrast, $V$. americana sapwood was the least resistant of the three durable wood species despite the higher wood extractive content. The weaker resistance of the sapwood was due to the high aqueous extract content, which certainly contained reserve material, a nutrient source for fungi (Table 1). At the intra-tree level, we confirmed that heartwood was more resistant than sapwood

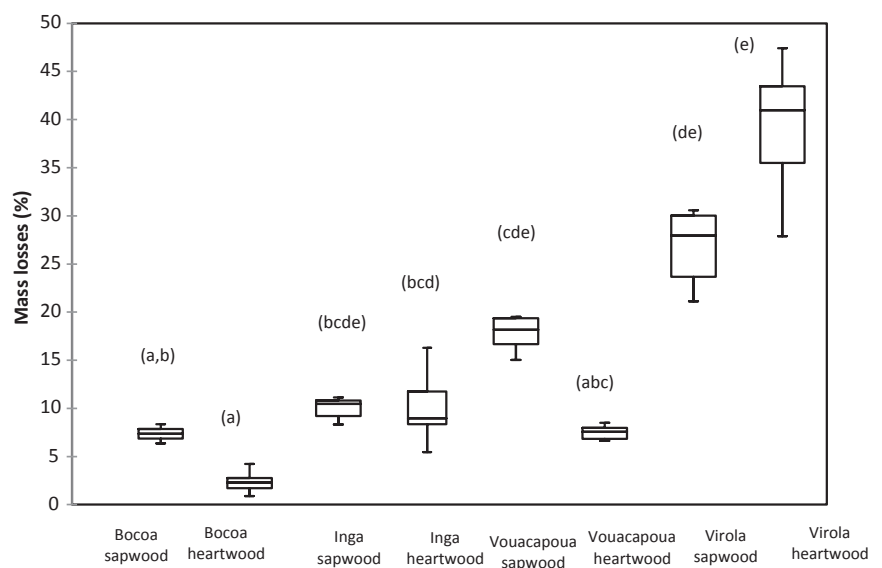

Fig. 3. Mass losses (as percentage) in both outermost heartwood and sapwood after 90 days exposure to soil microflora. V. michelii (Control), mass losses confirmed the virulence of soil microflora. Mass losses of $B$. prouacensis, V. americana, I. alba, with different letters are significantly different at $p<0.5$, as determined by the Kruskall-Wallis test followed by multiple pairwise comparisons using Dunn's procedure/two-tailed test. These results are an average of 12 replicates in both outermost heartwood and sapwood (Min, Max, Mean).

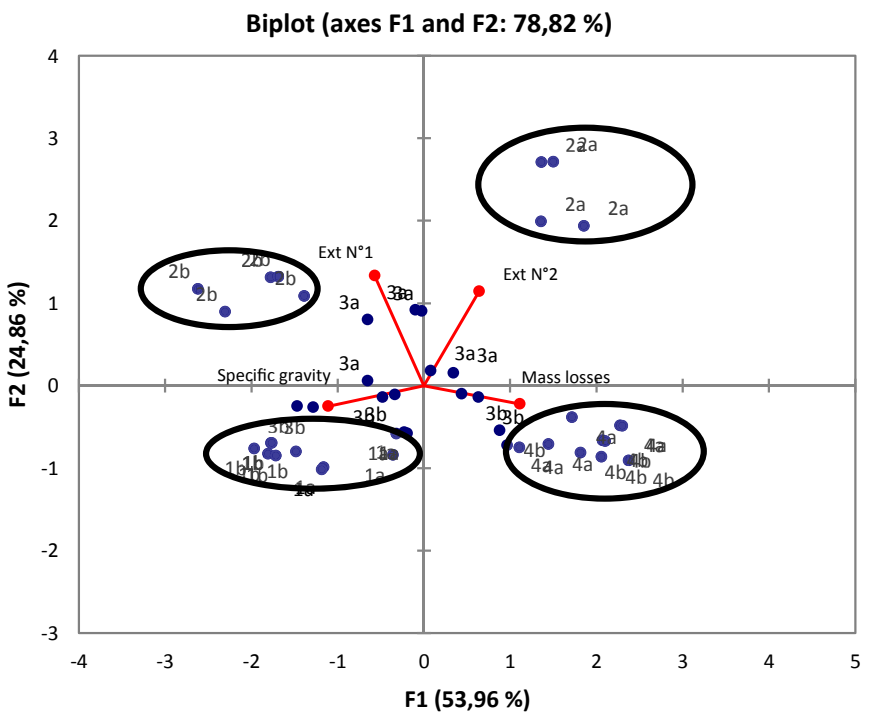

Fig. 4. Principal Component Analysis (PCA) graph visualizing correlation among decay resistance (mass losses), wood extractives content (Ext $\mathrm{N}^{\circ} 1$ ethanolic extraction; Ext $\mathrm{N}^{\circ} 2$ aqueous extraction) and density; with the B. prouacensis (1) V; americana (2) , I. alba (3), and: V. michelii (Control, 4) ; abbreviation a, sapwood; b, heartwood.

because of the heartwood formation process (Fig. 3). During this physiological process, there was an increase in wood extractive content in the heartwood, but this was not always the case, e.g. in I. alba where the total wood extractive content was twofold higher for sapwood compared to heartwood (13.1\% and 7.6\%, respectively).

\section{Discussion}

Overall, decay resistance, wood extractive content and density values were in accordance with those found in the literature (Scheffer and Morell, 1998; Paradis et al., 2012). Virulence of $V$. michelii (control), which has undifferentiated heartwood, were confirmed, i.e. there was no significant difference between sapwood and heartwood with respect to mass losses and total wood extractive content. Conversely, the results obtained with the three durable species showed that the high decay resistance of the heartwood was due to the heartwood formation process, which mobilized reserve material, thus generating a supply of carbon and energy for the biosynthesis of protective molecules.

\subsection{Diversity of the decay resistance strategy in three durable species}

This combined study of decay resistance, density and wood extractive content in sapwood and heartwood shed substantial 
light on the role of these properties in decay resistance. Our results highlighted three protection strategies of heartwood from three durable species. The first strategy was observed with B. prouacensis. After exposure to the soil microflora, this species showed the most efficient defense mechanisms, because the sapwood and the heartwood were the most resistant. The density contributed to the poor water uptake and influences the colonization by decay fungi during the decay test. Common sense holds also that high-density wood decays more slowly than low density wood (for a piece of given dry mass). Indeed, the comparison of the real mass loss (of wood matter) according to one cube meter of wood allows to conclude that $V$. michelii (control) were respectively two and sixfold more degraded than the sapwood and heartwood of $B$. prouacensis (data not shown). These results also confirmed that the heartwood formation process generates wood extractives which play a key role in heartwood decay resistance: with heartwood 2.5-fold more resistant than the sapwood.

$B$. prouacensis was the most resistant wood species with the lowest wood extractive content. This wood protection was due to the high level of fungicidal activity of compounds present in the sapwood and heartwood. The sapwood of $B$ prouacensis was also as resistant as the heartwood of $V$. americana. However, we also hypothesize that the superficial decay associated with the low extractive content was due to slow leaching of extractives from the wood surface or to slow extractives detoxification by the invasive soil microorganisms. Indeed, Monties (1991) reported that the accumulation of phenolic compounds during heartwood formation might involve enzymatically initiated but chemically driven copolymerisation between phenolic derivatives and the preexisting cell-wall macromolecular components, including lignins and lignin polysaccharide complexes which decrease the accessibility. The high density, high level of antifungal compounds or well-fixed compounds on the cell walls contributed to the decay resistance of heartwood and sapwood in B. prouacensis.

The second defense strategy was observed in $V$. americana. Despite the high wood extractive content $(17.5 \%)$, the sapwood was the most sensitive to soil microflora ( $16.6 \%$ mass loss). This weak resistance was due to the high level of reserve material. This hypothesis was corroborated by the fact that this species had the highest level of aqueous extracts (6.3\%) of the three species. This high level was due to the fact that a high level of wood extractives in heartwood requires a high level of reserve material for the carbon skeleton and an energy source for secondary metabolic pathway activation. However, sugars available in sapwood contribute to active colonization of wood tissues by decay fungi.

The results concerning the $V$. americana strategy also showed that during heartwood formation there was high synthesis of secondary metabolites which protect the heartwood (5.6\% mass loss) the heartwood was threefold more resistant than the sapwood. The decay resistance of heartwood was due to the density but also to the high level of wood extractives. We thus consider that its defense mechanism could be based on a synergetic effect of several compounds, as already observed with Eperua falcata (Rodrigues et al., 2009). Shultz and Nicholas (2002) reported that other properties such as antioxidant or metal chelator properties could contribute to the wood protection mechanism. In fact, in $V$. americana heartwood, Kido et al. (2003) isolated furanic terpenoid from the cassan-like methyl vouacapenate family, which has antibacterial and antioxidant properties (Dickson, 2007). Finally, the high density and high wood extractive content acted synergetically to contribute to the decay resistance of heartwood of $V$. americana. This high level of wood extractives could more easily leach, with one negative impact on decay resistance against soil microflora.
The third strategy was observed with I. alba, which had a lower density than the two previous studied wood species. There was no significant difference between sapwood and heartwood in mass losses. Likewise, heartwood formation was not characterized by a higher level of wood extractives as observed in B. prouacensis and $V$. americana, since the total extractive content was 1.7 -fold lower in heartwood than in sapwood. These results highlight the role of the chemical composition instead of the wood extractive content in decay resistance. We suggest that the wood tissue resistance was due to the presence of fungus inhibitory extractives. Rovira et al. (1999) also observed that I. alba bark is composed of polyphenolics and catechic tannin. These compounds are known for their biological activity, and it is possible that some of these compounds are also present in the wood. Despite the lower density in I. alba as compared to the other species, decay resistance after 90 days exposure was due to the high level of antifungal compounds or well-fixed compounds on the cell walls comparatively to V. americana.

These three strategies highlight the complexity of decay resistance origin in durable species. Several authors have discussed the role of density, extractive content and type, lignin content etc... Density affects plant biomechanics, drought and decay resistance, but there is controversy on this last point, i.e. some authors obtained a high correlation between decay resistance and density (Wong et al., 2005), and this correlation was more marked when we compared the durabilities of wood species of different densities. Our results showed that the wood extractive content or density relative to the wood decay resistance alone is not a good indicator of decay resistance.

The nature of the wood extractives plays a key role in species with intermediary density. Decay resistance is also dependent on the type of wood extractives, as we showed with I. alba and $V$. americana heartwood, which both have the same decay resistance level. $V$. americana heartwood is protected by the high level of synergetically acting extractives and high density. In contrast, I. alba showed the lowest wood extractive content, suggesting that these compounds have specific bioactivity against soil microflora. This study doesn't take into account the role of the non-polar compounds which also contribute to the hydrophobicity of the wood.

Finally, wood decay resistance is a consequence of functional traits like anatomical and defensive secondary compounds associated with lower risk of pathogen invasion. Heartwood formation preserves the integrity of the internal tissue of the tree in order to maintain the mechanical support function. However, this protection barrier could be implemented at an early stage in sapwood, due to the presence of chemical precursor with antifungal properties, as observed with $B$. prouacensis. Our findings provide new insight on wood decay resistance, particularly in tropical forest woods. Decomposition of woody plant tissue is an important component of the terrestrial carbon cycle, and a better understanding of its controlling factors is essential for predicting ecosystem responses to global change. Several authors used density to predict wood decay rate. Indeed, we believe that wood extractives must be taken into account particularly with wood species with intermediary density; when optimizing models for the prediction of net carbon flux and to quantify the degree to which forest ecosystems serve as a carbon sink or source.

\section{Conclusion}

The aim of our study was to highlight different decay resistance strategies in three durable wood species: B. prouacensis, $V$. americana and $I$. alba according the both wood properties: density and wood extractive content. Our results showed that decay resistance is more correlated with density than wood extractive content. But it 
is important to take the qualitative extractive aspects rather than the wood extractive content into account. We also highlighted three decay resistance strategies in three Neotropical wood species. First, the resistance of $B$. prouacensis was due to the high wood density which influences water uptake, the progression of mycelia in the cell walls, and very protective secondary metabolites already present in sapwood. Secondly, decay resistance was highly linked to the high wood extractive content in $V$. americana heartwood, suggesting that these metabolites act in synergy. Thirdly, in contrast, decay resistance in $I$. alba, the species with intermediary density and a low extractive content, may be due to the antifungal wood extractives synthesized early in the sapwood.

\section{Acknowledgment}

This work has benefited from an "Investissement d'Avenir" grant managed by Agence Nationale de la Recherche (CEBA, ref. ANR-10-LABX-0025).

\section{References}

AFNOR, 1942 NF B51-002 Février, 1942. Bois - Caractéristiques physiques et mécaniques des bois.

AWPA E14-07, 2007. Standard method of evaluating preservatives in a soil bed. American Wood Protection Association, 5pp.

Amusant, N., Fournier, M., Beauchene, J., 2008. Colour and decay resistance and its relationships in Eperua grandiflora. Ann. For. Sci. 65, 806-812.

Antwi-Boasiako, C., Pitman, A.J., 2009. Influence of density on the durabilities of three Ghanaian timbers. J. Wood Sci. Technol. 29, 34-45.

Chave, J., Muller-Landau, H., Barker, T.R., Easdale, T.S.A., Steege, H.T., Webb, C.O., 2006. Regional and phylogenetic variation of wood density across 2456 neotropical tree species. Ecol. Appl. 6, 2356-2367.

Chave, J., Coomes, D., Jansen, S., Simon, L.L., Swenson, N.G., Zanne, A.E., 2009. Towards a worldwide wood economics spectrum. Ecol. Lett. 12, 351-366.

Cornwell, W.K., Cornelissen, J.H.C., Steven, A., Bauhus, S., Eggleton, P., Preston, C.M., Scarff, F., Weedon, J., Wirth, C., Zanne, A.E., 2009. Plant traits and wood fates across the globe: rotted, burned, or consumed? Glob. Change Biol. 15, 2431-2449.

Cramer, W., Bondeau, A., Woodward, F.I., Prentice, I.C., Betts, R.A., Brovkin, V., Cox, P.M., Fisher, V., Foley, J.A., Friend, A.D., Kucharik, C., Lomas, M.R. Ramankutty, N., Sitch, S., Smith, B., White, A., Young-Molling, C., 2001. Global response of terrestrial ecosystem structure and function to $\mathrm{CO}_{2}$ and climate change: results from six dynamic global vegetation models. Glob. Change Biol. 7, 357-373.

Debell, J., Morrell, J.J., Gartner, B.L., 1999. Within-stem variation in tropolone content and decay resistance of second-growth western redcedar. For. Sci. 45, $101-107$.

Dickson, R.A., Houghton, P.J., Hylands, P.J., 2007. Antibacterial and antioxidant cassane diterpenoids from Caesalpinia benthamiana. Phytochemistry 68, 1436-1441.

Kido, T., Taniguchi, M., Baba, K., 2003. Diterpenoids from Amazonian crude drug of Fabaceae. Chem. Pharm. Bull. 51, 207-208.
Kolleman, F.F.P., Cote, W.A., 1984. Principles of Wood Science and Technology, vol. I. Solid Wood. Spinger-Vergal, 291 pp.

Monties, B., 1991. Plant cell as lignocellulosic composite: relations with lignin structures and functions. Animal Feed Sci. Technol. 32, 159-175.

Neya, B., Hakkou, M., Pétrissan, M., Gérardin, P., 2004. On the durability of Burked africana heartwood: evidence of biocidal and hydrophobic properties responsible for durability. Ann. For. Sci. 61, 277-282.

Niamké, F., Amusant, N., Stien, D., Chaix, G., Lozano, Y., Kadio, A.A., Lemenager, N., Goh, D.K.S., Adima, A.A., Kati-Coulibaly, S., Jay Allemand, C., 2012. 4', 5'-Dihydroxy-epiisocatalponol, a new naphthoquinone from Tectona grandis L. f. heartwood, and fungicidal activity. Int. Biodeterior. Biodegrad. 74, 93-98.

Nicholas, D.D., Crawford, D., 2003. Concepts in the development of new accelerated. Test methods for wood decay (Chapter 16). In: Goodell, B., Nicholas, D.D. Schultz, P. (Eds.), Wood Deterioration and Preservation Advances in Our Changing World. American Society, Washington D.C, pp. 288-312.

Paradis, S., Guibal, D., Vernay, M., Beauchêne, J., Brancheriau, L., Châlon, I, Daigremont, C., Détienne, P., Fouquet, D., Langbour, P., Lotte, S., Méjean, M. Thévenon, M.F., Thibaut, B., Gérard, J., 2012. Tropix ${ }^{\mathbb{B}} 7$, logiciel du CIRAD.

Rodrigues, A.M.S., Royer, M., Amusant, N., Beauchene, J., Herbette, G., Eparvier, V. Thibaut, B., Salmen, L., Thibaut, B., Stien, D., 2009. Antinomic naturalnelf-protection mechanism in long-lasting woods:a case study with three tropical species from French Guiana. IRG/WP 09-10696. The International Research Group on Wood Preservation, Beijing.

Rodrigues, A.M.S., Amusant, N., Beauchêne, J., Eparvier, V., Lemenager, N. Baudasse, C., Espíndola, L.S., Stien, D., 2011. The termiticidal activity of Sextonia rubra (Mez) van der Werff (Lauraceae) extract and its active constituen rubrynolide. Pest Manag. Sci. 67, 1420-1423.

Rovira, I., Berkov, A., Parkinson, A., Tavakilian, G., Mori, S., Meurer-Grimes, B., 1999. Antimicrobial activity of neotropical wood and bark extracts. Pharm. Biol. 37, 208-215.

Scheffer, T.C., Morrell, J.J., 1998. Natural Durability of Wood: a Worldwide Checklist of Species by Research Contribution 22. Forest Research Laboratory. Oregon State University.

Sousa-Correia, C., Alves, A., Rodrigues, C.J.,Ferreira-Dias, S, Abreu, J.M., Maxted, N. Ford-Lloyd, B., Schwanninger, M., 2007. Oil content estimation of individual kernels of Quercus ilex subsp rotundifolia [(Lam) O. Schwarz] acorns by Fourier transform near infrared spectroscopy and partial least squares regression. J. Near Infrared Spectrosc. 01, 247-260.

Syafii, W., Yoshimoto, T., Samejima, M., 1988. The effect of lignin structure on decay resistance of some tropical woods, pp. 69-77. Bulletin of the Tokyo University Forests 80.

Taylor, A.M., Gartner, B., 2002. Heartwood formation and natural durability. A review. Wood Fiber Sci. 34, 587-611.

Van Geffen, K.G., Poorter, L., Ass-Klaassen, U., Van Logtestijn, R.S.P., Cornelissen, J.C., 2010. The trait contribution to wood decomposition rates of 15 Neotropical tree species. Ecology 91, 3686-3697.

Weedon, J.T., Cornwell, W.K., Cornelissen, J.H.C., Zanne, A., Wirth, C., Coomes, D. 2009. Global meta-analysis of wood decomposition rates: a role for trait variation among tree species. Ecol. Lett. 12, 45-56.

Wong, A.H.H., Kim, Y.S., Singh, A.P., Ling, W.C., 2005. Natural durability of tropical Species with emphasis on Malaysian hardwood-variation and Prospects. Document No:IRG/WP 05-10568. The International Research Group on Wood Protection Bengalor.

Yamamoto, K., Hong, L.T., 1994. A Laboratory method for predicting the durability of tropical hardwoods. Japan International Research Centre for Agricultural Sciences. J. Agric. Res. Quat. 28, 268-275. 